\title{
THE ROLE OF HUMAN FACTOR AND HRM PRACTICES IN MNCS' PERFORMANCE IN EASTERN AND WESTERN EUROPE - A COMPARATIVE ANALYSIS OF THE RESEARCH FINDINGS
}

\author{
Marzena Stor ${ }^{1}$, Lukasz Haromszeki ${ }^{2}$ \\ Human Resources Management Departemnt, Wrocław University of Economics \& Business, \\ ul. Komandorska 118/120; 53-345 Wroctaw, Poland \\ E-mails: ${ }^{1}$ marzena.stor@wp.pl (corresponding author); ${ }^{2}$ lukasz.haromszeki@ue.wroc.pl
}

Received 21 February 2020; accepted 07 May 2020

\begin{abstract}
The main goal of the paper is to identify, analyze, and compare the relationships between the activities in the field of HRM and performance results of MNCs in Eastern and Western Europe with a view to the value ascribed to human resources as a strategic competitive factor, HRM centralization practices and the importance of HRM knowledge flows between the headquarters (HQ) and their subsidiaries. The research sample covered $200 \mathrm{HQs}$ of MNCs and their local subsidiaries. The empirical research results show that there are some identifiable and statistically significant differences between MNCs operating in Eastern and Western Europe within the range of relationships defined above. Our study, therefore, represents an original effort at examining these relationships.
\end{abstract}

Keywords: HRM, human factor, performance results, multinational company, Eastern Europe, Western Europe, centralization, knowledge flow.

JEL Classification: M12, M16, F23.

\section{Introduction}

The role of human factor and human resources management (HRM) practices in organizational performance have been studied in many ways and in different geographical regions. On the whole, the research results suggest the positive role both of the quality of human factor (Chen, 2014) and HRM outcomes towards organizational performance results (Katou \& Budhwar, 2010a).

However the regions are different because of their international competitiveness, innovation index, environmental friendliness for doing business, the economic freedom, perception of corruption, GDP, culture, history and many others (Kiselakova et al., 2019). For the Europeans there are even obvious difference between the internationalization processes of various state and social processes in Eastern and Western Europe (Ferencikova \& Hluskova, 2015). This partly explains why some multinational companies (MNCs) have better performance results with comparison to domestic companies (Avarmaa et al., 2013; Rajnoha et al., 2018), although from the MNC's perspective it is much more complicated to conduct business abroad than in own country. For them understanding local environmental demands is of crucial importance in order to properly evaluate which kind of organization- al practices their subsidiaries need to develop into high-performance entities. That is why the MNCs that find some of their human factor features and HRM practices remarkably important to their local performance success may impose some different HRM policies to ensure that the behaviors of employees are properly influenced and led in an intended direction (Berchtold et al., 2010). Such policies may cover the functional structure of HRM, its centralization and advancement level, assumptions connected with HRM contribution to organizational performance and even the significance of the direction in which the HRM knowledge flows between the MNC's headquarters (HQ) and its local subsidiary (Al-Hakim \& Hassan, 2016). The research shows that knowledge assets and employee competencies are becoming significantly important for a firm's performance and competitiveness. And because the entirety of human capital is held by employees it is the aim of management is to pass human capital in the form of employees' special skills on to a network of many people, where it is fertilized and transferred to the ownership of the company (Gomezelj \& Antončič, 2015). What is more, the knowledge and experience of senior managers and the workforce are seen as valuable assets which are costly to replace or to rebuild (Brauer, 2013). 
In this context the main goal of the paper is to identify, analyze, and compare the relationships between the activities in the field of HRM and performance results of MNCs in Eastern and Western Europe with a view to the value ascribed to human resources as a strategic competitive factor, HRM centralization practices and the importance of HRM knowledge flows between the headquarters (HQ) and their subsidiaries.

In consequence the paper is structured as follows. After this short introduction the authors discuss the theoretical background of the study based a literature review. This results in formulation of the main research questions and hypotheses in the next section. Furthermore, the focus is on the research methodology, sample and measures. The empirical research findings and discussion over them come next. The article ends with a research summary and final conclusions.

\section{The theoretical background of the study}

\subsection{HRM advancement level and performance results}

There are numerous publications in which the authors present empirical research findings on the relationship between the HRM advancement level and organizational performance results. Unfortunately, in many cases their research findings are incomparable. It is because they apply different performance indicators (Ginevičius et al., 2010; Villajos et al., 2019), some of them focus on the overall HRM advancement level or significance to the company's results, whereas others consider individual contribution of particular HRM subfunctions to the organizational performance results (Ginevičius et al., 2010). At best, we can differentiate four general categories of company's performance results which the researchers have proved to be correlate with HRM practices. One of them refers to the financial results and covers profits, sales, market share, financial liquidity, company's goodwill, share price, firm value (Richey \& Wally, 1998; Pfeffer \& Veiga, 1999; Arthur, 1994; MacDuffie, 1995; Huselid, 1995; Becker \& Gerhart, 1996; Beatty et al., 2003; Combs et al., 2006). The second category is named the organizational results and includes productivity, quality of products/services, efficiency, innovativeness, competitive advantage (Arthur, 1994; Huselid, 1995; Becker \& Gerhart 1996; Huselid et al., 1997; Pfeffer \& Veiga 1999; Birdi et al., 2008; Ferguson \&
Reio, 2010; Sparrow et al., 2016; Paawe \& Ferndale, 2017). The managerial results make the third category and refer to the research on interrelations and levels of coherence between business strategies and particular subfunctions of HRM with company's performance results (Beer et al., 1984; Schuler \& Jackson, 1987; Wright \& Snell, 1991; Guest, 1997; Chanda \& Shen, 2009; Guest et al., 2011; Stor \& Suchodolski, 2016). The last, but not the least, is the category of behavioral results which cover employee attitudes, employee engagement and satisfaction, employee and/ or managerial interpersonal relations, employee competency development, leadership (Nagy, 2002; Rich et al., 2010; Ferguson \& Reio, 2010; Juchnowicz, 2014; Sparrow et al., 2016; Stor \& Haromszeki, 2019). All in all, there is a vast array of various approaches to the relationships between the HRM advancement level and organizational performance results.

\subsection{The value of human competitive factor: non-managerial and managerial}

In their business practice companies may use different competitive factors (Nasab et al., 2013), as to mention price for each sale, profit margin, quality of design or manufacturing, features and quality of service, technology, reputation and human resources on which everything is built upon. The analysis of the literature suggests that human resources are of the fundamental importance to business success and its ability to gain competitive advantage. It is because the realization of business strategies and attainment of intended organizational results depend, of course among other things, on the human resources that a company possesses (Katou \& Budhwar, 2010b; Kearns, 2010) and which can be perceived as a competitive factor of a company. This view has been present within the resource-based theory for nearly 30 years (Barney, 1991; Dyer, 1993; Wright et al., 1993; Becker et al., 2001; Huselid \& Becker, 2011) and has been supported both by the rationally formulated theoretical conceptions and by the empirical research findings (Andersen, 1993, p. 211; Ingham, 2007; Mayo, 2012; Juchnowicz, 2014; Żarnik-Żuławska, 2016, p. 15; Delery \& Roumpi, 2017). Human resources are of course diverse as their owners, meaning people, are diverse. Employees differ in their abilities, skills, knowledge, needs, professional backgrounds, etc. and thus may have varying responses to HRM practices. Consequently, some disaggregation of employees into specific groups is reasonable and worth a more comprehensive look (Kazlauskaitė \& Bučiūnienè, 2010). In 
research and business practice the human factor as a competitive factor is usually structured of nonmanagerial employees and managerial staff because of the different competencies required from them (Witek-Hajduk, 2010; Sienkiewicz, 2014; Stor, 2014; Kupczyk \& Stor, 2017; Doornich, 2018), a different range of responsibilities ascribed to these two groups and a different scale of consequences that their decisions may bring to a company (Karaszewski, 2013; Latusek-Jurczak, 2014; Stor \& Suchodolski, 2016). So, it leads to a conclusion, which is taken for granted in the HRM literature, that the value of the human factor as a competitive factor is a resultant of how people have been managed. But the relationship can be reciprocal. A company may invest in people management depending on how it perceives its significance to the company's success (Stor \& Haromszeki, 2019). Hence, the significance ascribed to HRM for its contribution to the organizational performance results may depend on the value ascribed to the human factor and at the same time may determine the level of HRM centralization and direction of HRM knowledge flow between the MNC's HQ and its local subsidiary.

\subsection{HRM centralization \& HRM knowledge flow}

The appraisal of human factor as a company's competitive factor goes in line with a broader discussion of the centralization and decentralization practices within management at different organizational levels and in different HRM areas and how these practices may underpin or encumber the performance of a company. Some authors argue that in MNCs the headquarters-subsidiary relationship in each context is a differentiated combination of centralization. Moreover, the considerations also include the direction of knowledge flows, whether it is from the headquarters of MNC to its local subsidiary, in the opposite direction or in both (see e.g. Slangen, 2011). Some research suggests that when a subsidiary has more advanced resources in terms of knowledge than other units in a MNC, knowledge is likely to transfer from this subsidiary to other parts of the MNC (Ghoshal \& Nohria, 1993; Bjorkman et al., 2004; Wang et al., 2004). The competitive advantage of MNCs lies in their ability to exploit locally created knowledge worldwide, and in their capabilities to transfer knowledge within organizational networks characterized by separation through time, space, culture and language (Birkinshaw et al., 1998; Kogut \& Zander, 1993). The efficiency of HRM centralization practices and preferable direction of HRM knowledge flow may be conditioned by the appraisal of human factor as a competitive factor and different expectations resulting from it (Zoghi \& Mohr, 2011).

\subsection{Eastern and Western Europe as the regions of research interests}

Before the social, political and economic reforms of 1989 (i.e. the collapse of socialism) the Europe had been perceived by the Europeans themselves as composed of two worlds: Western Europe and Eastern Europe. In those days Western Europe had been called the Capitalist Block and Eastern Europe - the Socialist Bloc or the Soviet Block because it had made the group of socialist countries under the influence and control of the Soviet Union. For decades these two regions had been developing under completely different political and economic régime bringing even differentiable societal developments (Apsalone \& Šumilo, 2015) and resulting in different leadership styles and conceptualizations of appropriate management decisions. Prior to the changes that took place at the end of the 1980s, it had been even the state that controlled HRM activities in most East European countries (Listwan et al., 2009). Since the end of the Socialist Block the financial and economic growth have accelerated but on average it's still lower with comparison to Western Europe (Stawicka, 2014; Skare \& Porada-Rochoń, 2019). And the social, organizational and managerial changes, although visible all around, are not free of the encounters with the past authoritarian/patriarchal managerial models. For thirty years now Eastern Europeans have been trying to come closer to Western Europe. In the whole history of European civilization this period looks very short but it justifies why it is reasonable to consider the personnel practices in MNC headquartered in Eastern Europe with comparison to those originating from Western Europe. So far only a few studies have focused on some of the above mentioned phenomena in economies such as in Eastern Europe (Farndale et al., 2017, p. 1630). In most cases the research on MNCs has covered the companies deriving from developed countries (usually from the West) whose foreign direct investment (FDI) was located in less developed countries (e.g. Brewster, 2007; Hyder \& Abraha, 2008; Karoliny et al., 2009; Listwan et al., 2009; Morley et al., 2009; Brewster et al., 2010; Sahadev \& Demirbag, 2010; Kshetri, 2010; Brunet-Thornton, 2017; Dickmann et al., 2016; Wilkinson \& Wood, 2017). No specific research of this scope has been performed in MNCs headquartered in economies in transition or just after-the- 
transition, like those in Eastern Europe (Festing \& Sahakiants, 2013; Götz, 2014; Haromszeki, 2014; Stor \& Kupczyk, 2015; Trąpczyński, 2015; Chen, 2016; Stor, 2016; Koster \& Wittek, 2016; Poór et al., 2017). Then, the more complex and interrelated ties between the appraisal of human factor as a competitive factor, the advancement level and significance of HRM to organizational performance, its centralization and directions of knowledge flow stay rather unknown.

\section{Research questions \& hypothetical answers}

The literature review and accompanying theoretical considerations have resulted in five major fields of our scientific interests and six corresponding research questions as presented below. We have also developed six hypothetical answers. Because of the publication limits some of the hypotheses are of a compound character.

\section{HRM and performance results}

Q1: In what range do the companies' performance results in HRM determine the results in other performance fields like finance, quality of products/services and innovativeness?

$\mathbf{H}_{1}$ : The higher the subsidiary's performance results in HRM, the higher its results in finance, quality of products/services and innovativeness.

\section{Competitiveness of human factor and perfor- mance results}

$\mathbf{Q}_{2}$ : Is there a relationship between the appraisal of human factor (competencies of managerial staff and knowledge \& skills of non-managerial employees) as a companies' competitive factor and the companies' performance results (in HRM, finance, quality of products/services and innovativeness)?

$\mathbf{H}_{2}$ : The higher the appraisal of human factor (both managerial and non-managerial) as a company's competitive factor, the better the companies' performance results in HRM, finance, quality of products/services and innovativeness.

\section{Appraisal of human factor and HRM centrali- zation \& knowledge flow}

Q3: Does an increase in the appraisal of human factor (both managerial and non-managerial) as a company's competitive factor results in higher level of HRM centralization and higher significance of HRM knowledge flows between the HQ and local subsidiaries?

$\mathbf{H}_{3}$ : The higher the appraisal of human factor (both managerial and non-managerial) as a company's competitive factor, the higher the HRM centralization level and the higher the significance of HRM knowledge flows from the HQ to its local subsidiary and in the opposite direction.

Q4: Does an increase in the significance of HRM to the subsidiary's performance results raise the level of HRM centralization and the significance of HRM knowledge flows between the HQ and local subsidiaries?

$\mathbf{H}_{4}$ : The higher the significance of HRM to the subsidiary's performance results, the higher the HRM centralization level and the higher the significance of HRM knowledge flows from the HQ to its local subsidiary and the opposite direction.

\section{HRM significance \& advancement level, human} factor and performance results

Q5: Is the HRM advancement level associated with the company's performance overall results, the appraisal of human factor (both managerial and non-managerial) as a company's competitive factor and the significance of HRM to the subsidiary's performance results?

H5: The higher the HRM advancement level, the higher the company's performance overall results, the higher the appraisal of human factor (both managerial and non-managerial) as a company's competitive factor, and the higher the significance of HRM to the subsidiary's performance results.

\section{The HRM practices of MNCs in Eastern and Western Europe}

Q6: Are there any identifiable differences between Eastern and Western Europe within the scope of problems outlined in the above questions?

$\mathbf{H}_{6}$ : There are some identifiable and statistically significant differences between MNCs operating in Eastern and Western Europe within the range of relationships defined in the above hypotheses.

\section{The empirical research methodology}

In our research we were interested in identification, analysis, and comparison of the relationships between the activities in the field of HRM and performance results of multinational companies (MNCs) in Eastern and Western Europe with a view to the value ascribed to human resources as a strategic competitive factor, HRM centralization practices and the importance of HRM knowledge flows between the headquarters (HQ) and their subsidiaries. In a result of theoretical studies, we have formulated six research questions and corresponding hypotheses to be verified in the empirical 
research. Both of them were presented in the previous section.

The company performance results (as a dependent variable) were rated in four areas: financial results, quality of products/services, innovativeness, and HRM itself. The activities in the field of HRM (as an independent variable) were analyzed on the basis of their significance (understood as contribution as well) to the foreign subsidiary performance results, their advancement level, the degree to which strategic decisions (and control) within their scope are made at the foreign entity level (centralization vs decentralization), and the importance of knowledge flows within their range to/from the HQ. The activities within HRM covered such 9 subfunctions as: employee resourcing and retention, shaping their work engagement and satisfaction, performance appraisal, career development, talent management, competency management, development of leadership traits and relationships, and employer branding. The HRM significance and HRM advancement level were calculated as a mean of all the 9 subfunctions. Additional attention was paid to the position that human resources occupy among the competitive factors of the MNCs. The appraisal of human resources as a company's competitive factor was split into two other factors: (1) non-managerial employees' skills and knowledge and (2) managerial staff's competencies. The measures and scales used to the particular variables incorporated in the tested hypotheses are presented in Table 1.

The data has been collected in two ways: CATI (computer aided telephone interview) and CAWI (computer aided Web interview). To analyze the collected data both descriptive and correlational statistical methods were used. All the questions were asked in the context of the last two fiscal years and the interviewer reminded the respondents of that several times during the interview survey. The goal of this procedure was to ensure that the respondent was referring to a specific period of time in which he or she was able to logically assess the interconnections between the particular HRM and business phenomena under study. The survey was conducted in January 2018. All calculations were performed using Statistica v. 12.5 - an advanced analytics software package with the level of significance set to alpha L' 0.05 . Kolmogorov-Smirnow test was performed to determine the normality of data distribution. The relationships between the quantitative variables were examined by the means of Pearson correlation coefficient (referred to as Pearson's r).

The research sample was composed of 200 headquarters of MNCs deriving from a Central European country (Poland). They were nonfinancial economic entities, existing on the market no less than two years, with a dominant share of the Polish capital, which possessed at least one foreign subsidiary, and this subsidiary was an effect of a foreign direct investment (FDI). The reference base for the number of business entities was the last report prepared by the Polish Central Statistical Office. The report said that there were 1760 Polish economic entities which confirmed possessing 4086 business entities in 150 countries in 2015 (Activities of Enterprises..., 2017). Hence, it was assumed that the size of a sample is sufficient to conduct the research because when the confidence coefficient stays at the level of 0.95 the maximum measurement error amounts to 0.065 .

The sampling was of the purposive type to meet the requirements specified above. The structure of the research sample was diverse in terms of the companies' business profiles - according to the European Classification of Business Activity (ECBA) - although not all of the sectors of the economy were represented; length of operation in years; size of organizations (as measured by number of employees); type of FDI investment; and the ownership share of the HQs in their foreign subsidiaries. Furthermore, the MNCs under research differed in the number of total and foreign entities they controlled, number of host countries in which their subsidiaries were located, and level of country's development in which their most representative subsidiary operated. An average MNC operated on the market longer than 11 years, was rather a large organization as measured by the number of employees, had about 13 entities, about 8 of them were foreign subsidiaries, located in 4 countries, established as greenfield investment with a majority ownership share belonging to the Polish HQ. We have analyzed 83 the biggest foreign subsidiaries of such companies in Eastern Europe and 102 in Western Europe.

We assumed that some specific parameters, for example, an industrial area, size of the company, its legal form or country's economic development could influence the performance of businesses in the sample. Results of statistical testing did not demonstrate the impact of these parameters on business performance. 
Table 1. Basic descriptive statistics for the variables characterizing company performance, competitive factors and HRM in MNCs in the research sample (source: own research data)

\begin{tabular}{|c|c|c|c|c|c|c|c|}
\hline Variables & Region & Valid & Mean & Median & Min & Max & $\mathrm{SD}$ \\
\hline \multirow{3}{*}{ Financial results } & World & 200 & 3.74 & 4.00 & 2.00 & 5.00 & 0.51 \\
\hline & E. Europe & 83 & 3.72 & 4.00 & 2.00 & 4.00 & 0.48 \\
\hline & W. Europe & 102 & 3.79 & 4.00 & 2.00 & 4.00 & 0.47 \\
\hline \multirow{3}{*}{ Quality of products/services results } & World & 200 & 3.26 & 3.00 & 2.00 & 5.00 & 0.50 \\
\hline & E. Europe & 83 & 3.29 & 3.00 & 3.00 & 5.00 & 0.51 \\
\hline & W. Europe & 102 & 3.23 & 3.00 & 2.00 & 5.00 & 0.47 \\
\hline \multirow{3}{*}{ Innovativeness results } & World & 200 & 3.32 & 3.00 & 2.00 & 5.00 & 0.52 \\
\hline & E. Europe & 83 & 3.28 & 3.00 & 3.00 & 5.00 & 0.48 \\
\hline & W. Europe & 102 & 3.35 & 3.00 & 2.00 & 5.00 & 0.54 \\
\hline \multirow{3}{*}{ HRM results } & World & 200 & 3.56 & 4.00 & 2.00 & 5.00 & 0.54 \\
\hline & E. Europe & 83 & 3.49 & 3.00 & 3.00 & 5.00 & 0.53 \\
\hline & W. Europe & 102 & 3.61 & 4.00 & 2.00 & 5.00 & 0.53 \\
\hline \multirow{3}{*}{ Mean of overall performance results } & World & 200 & 3.47 & 3.50 & 2.50 & 4.50 & 0.33 \\
\hline & E. Europe & 83 & 3.45 & 3.50 & 2.75 & 4.25 & 0.30 \\
\hline & W. Europe & 102 & 3.50 & 3.50 & 2.50 & 4.50 & 0.34 \\
\hline \multirow{3}{*}{ Mean of HRM significance to results } & World & 200 & 3.41 & 3.33 & 2.56 & 4.89 & 0.37 \\
\hline & E. Europe & 83 & 3.44 & 3.44 & 2.56 & 4.89 & 0.37 \\
\hline & W. Europe & 102 & 3.39 & 3.33 & 2.56 & 4.67 & 0.38 \\
\hline \multirow{3}{*}{$\begin{array}{l}\text { Competitive factor: non-managerial } \\
\text { employees }\end{array}$} & World & 200 & 3.41 & 3.00 & 2.00 & 5.00 & 0.56 \\
\hline & E. Europe & 83 & 3.41 & 3.00 & 2.00 & 5.00 & 0.63 \\
\hline & W. Europe & 102 & 3.38 & 3.00 & 2.00 & 4.00 & 0.51 \\
\hline \multirow{3}{*}{ Competitive factor: managerial staff } & World & 200 & 3.37 & 3.00 & 2.00 & 5.00 & 0.56 \\
\hline & E. Europe & 83 & 3.42 & 3.00 & 2.00 & 5.00 & 0.54 \\
\hline & W. Europe & 102 & 3.32 & 3.00 & 2.00 & 4.00 & 0.58 \\
\hline \multirow{3}{*}{$\begin{array}{l}\text { Mean of overall human factor: employees \& } \\
\text { managers }\end{array}$} & World & 200 & 3.39 & 3.50 & 2.00 & 4.50 & 0.46 \\
\hline & E. Europe & 83 & 3.42 & 3.50 & 2.50 & 4.50 & 0.49 \\
\hline & W. Europe & 102 & 3.35 & 3.50 & 2.00 & 4.00 & 0.45 \\
\hline \multirow{3}{*}{ Mean of HRM centralization } & World & 200 & 2.60 & 2.67 & 1.00 & 3.78 & 0.41 \\
\hline & E. Europe & 83 & 2.66 & 2.67 & 1.00 & 3.78 & 0.39 \\
\hline & W. Europe & 102 & 2.56 & 2.67 & 1.00 & 3.44 & 0.39 \\
\hline \multirow{3}{*}{ Mean of HRM knowledge flow from the HQ } & World & 200 & 3.44 & 3.44 & 2.44 & 4.78 & 0.38 \\
\hline & E. Europe & 83 & 3.41 & 3.44 & 2.44 & 4.33 & 0.35 \\
\hline & W. Europe & 102 & 3.46 & 3.44 & 2.56 & 4.67 & 0.36 \\
\hline \multirow{3}{*}{ Mean of HRM knowledge flow to the HQ } & World & 200 & 3.23 & 3.22 & 1.33 & 5.00 & 0.43 \\
\hline & E. Europe & 83 & 3.19 & 3.22 & 1.33 & 5.00 & 0.43 \\
\hline & W. Europe & 102 & 3.28 & 3.33 & 1.44 & 4.00 & 0.38 \\
\hline \multirow{3}{*}{ Advancement level of HRM } & World & 200 & 3.26 & 3.22 & 2.67 & 4.56 & 0.30 \\
\hline & E. Europe & 83 & 3.30 & 3.33 & 2.67 & 4.00 & 0.27 \\
\hline & W. Europe & 102 & 3.21 & 3.11 & 2.67 & 4.00 & 0.29 \\
\hline \multicolumn{8}{|c|}{$\begin{array}{l}\text { Scales: } \\
\text { Performance results: comparison to the main competitors: } 1 \text { - poor, } 2 \text { - below average, } 3 \text { - similar to others, } 4 \text { - above average, } 5 \text { - } \\
\text { very good; } \\
\text { Significance of HRM to performance results: } 1 \text { not important, } 2 \text { - slightly important, } 3 \text { - moderately important, } 4 \text { - important, and } 5 \text { - } \\
\text { very important; } \\
\text { Competitive factor: comparison to the HQ: } 1 \text { - strongly lower, } 2 \text { - rather lower, } 3 \text { - similarly to an average, } 4 \text { - rather higher, } 5 \text { - } \\
\text { strongly higher; } \\
\text { HRM centralization: } 1 \text { - decentralization (each subsidiary has full autonomy), } 2 \text { - general guidelines and framework provided by the } \\
\text { HQ, } 3 \text { - detailed policies, procedures and rules provided by the HQ, and } 4 \text { - centralization (centralized decision-making and tight } \\
\text { control over realization); } \\
\text { HRM knowledge flow: } 1 \text { - not important, } 2 \text { - slightly important, } 3 \text { - moderately important, } 4 \text { - important, and } 5 \text { - very important; } \\
\text { HRM advancement level: comparison to the main competitors: } 1 \text { - strongly lower, } 2 \text { - rather lower, } 3 \text { - similarly to an average, } 4 \text { - } \\
\text { rather higher, } 5 \text { - strongly higher. }\end{array}$} \\
\hline
\end{tabular}




\section{The empirical research findings}

\subsection{Descriptive statistics}

The basic descriptive statistics for the variables connected with the main research problem are presented in Table 1. On average, the worldwide performance results of MNCs, when compared to their main competitors, are somewhere between "similar to others" and "above average" $(\bar{x}=3.47)$.

The best score is achieved in finance $(\bar{x}=3.74)$, and the others in descending order are: HRM $(\bar{x}=3.56)$, innovativeness $(\bar{x}=3.32)$, and quality $(\bar{x}=3.26)$. The quality results in Eastern Europe $(\bar{x}=3.29)$ are a little higher than in Western Europe $(\bar{x}=3.23)$, but in Western Europe the other performance areas gain slightly better results. The significance of HRM to the subsidiary's performance results in the World is slightly above "moderately important" $(\bar{x}=3.41)$ like in other two regions under study, albeit in Eastern Europe is higher $(\bar{x}=3.44)$ than in Western Europe $(\bar{x}=3.39)$. The average advancement level of HRM worldwide $(\bar{x}=3.26)$ is similar to the level observed among the main competitors and never strongly lower when analyzed individually $(\mathrm{min}=$ 2 ), although again it is a little higher in Eastern Europe $(\bar{x}=3.30)$ than in Western Europe $(\bar{x}=3.21)$. The HQ usually plays an important role in determining detailed policies, procedures and rules for HRM at a subsidiary level, hence, exhibiting some control mechanisms. Redecoding the centralization scale (to: 1 - none, 2 - low, 3 - high, 4 -strong), the level of centralization worldwide is rather high $(\bar{x}=2.60)$, and at the same time is higher in Eastern Europe $(\bar{x}=2.66)$ with comparison to Western Europe $(\bar{x}=2.56)$. Considering in the worldwide perspective, the significance of HRM knowledge flow from the HQs to their local subsidiaries $(\bar{x}=3.44)$ and in the opposite direction $(\bar{x}=3.23)$ is even more than moderately important. Anyway, in Western Europe it is greater than in Eastern Europe. Finally, the human resources worldwide as a competitive factor are on average evaluated similarly to the human resources at the HQs $(\bar{x}=3.39)$. This refers both to the nonmanagerial $(\bar{x}=3.37)$ and managerial employees $(\bar{x}=3.41)$. None of the MNCs gives a rate of strongly lower $(\min =2)$. Furthermore, in Eastern Europe non-managerial employees $(\bar{x}=3.41)$ as well as managerial staff $(\bar{x}=3.42)$ are appraised higher than in Western Europe $(\bar{x}=3.38$ and $\bar{x}=3.32$ respectively). What is more, in Eastern Europe among eight competitive factors it is competencies of managerial staff that is placed on the second position (after the quality of products/services) and knowledge \& skills of employees coming third, whereas in Western Europe competencies of managerial staff are on the fourth position and knowledge \& skills of employees on the third (see Table 2).

Table 2. The ranking of competitive factors (source: own research data)

\begin{tabular}{|c|c|c|}
\hline No & Competitive factors & $\begin{array}{l}\text { Mean } \\
\text { value }\end{array}$ \\
\hline \multicolumn{3}{|c|}{ World } \\
\hline 1. & Quality of products/services & 3.78 \\
\hline 2. & Knowledge \& skills of employees & 3.41 \\
\hline 3. & Structure \& size of organization & 3.39 \\
\hline 4. & Competencies of managerial staff & 3.37 \\
\hline 5. & Financial resources & 3.25 \\
\hline 6. & Low production cost & 3.20 \\
\hline 7. & Innovativeness of products/services & 3.14 \\
\hline 8. & Production technology & 3.10 \\
\hline \multicolumn{3}{|c|}{ Eastern Europe } \\
\hline 1. & Quality of products/services & 3.77 \\
\hline 2. & Competencies of managerial staff & 3.42 \\
\hline 3. & Knowledge \& skills of employees & 3.41 \\
\hline 4. & Structure \& size of organization & 3.28 \\
\hline 5. & Financial resources & 3.22 \\
\hline 6. & Innovativeness of products/services & 3.16 \\
\hline 7. & Low production cost & 3.16 \\
\hline 8. & Production technology & 3.14 \\
\hline \multicolumn{3}{|c|}{ Western Europe } \\
\hline 1. & Quality of products/services & 3.78 \\
\hline 2. & Structure \& size of organization & 3.52 \\
\hline 3. & Knowledge \& skills of employees & 3.38 \\
\hline 4. & Competencies of managerial staff & 3.32 \\
\hline 5. & Financial resources & 3.27 \\
\hline 6. & Low production cost & 3.22 \\
\hline 7. & Innovativeness of products/services & 3.10 \\
\hline 8. & Production technology & 3.04 \\
\hline
\end{tabular}

\subsection{Correlation analysis}

The results of the correlation tests (at $p<.05$ ) for the main research variables are presented in Table 3 (for Eastern Europe) and Table 4 (for Western Europe). Their analysis leads to the conclusion that in both regions the better the company's performance results in HRM, the better the subsidiary's performance overall results, although this correlation is stronger in Western Europe 
$(r=0.79)$ than in Eastern Europe $(r=0.67)$. In both regions the HRM results are also positively correlated with the financial results and innovativeness results. Interestingly, the relationship between the HRM results and financial results is slightly stronger in Eastern Europe ( $r=0.26$ cf. to $r=0.23$ ), whereas between the HRM results and innovativeness the strength of correlation is doubled in Western Europe ( $r=0.48$ cf. to $r=0.24)$. No statistically significant relationship has been found between the results in HRM and the quality of products/services.

Table 3. The results of a correlation test for the main research variables: company performance, competitive factors and HRM in Eastern Europe (source: own research data)

\begin{tabular}{|c|c|c|c|c|c|c|c|c|c|c|c|c|c|}
\hline Variables & 1. & 2. & 3. & 4. & 5. & 6. & 7. & 8. & 9. & 10. & 11. & 12. & 13. \\
\hline 1. Financial results & 1.00 & -0.01 & 0.06 & $0.26 *$ & $0.51 *$ & -0.15 & -0.07 & -0.06 & -0.07 & 0.05 & 0.17 & $0.32 *$ & $0.22 *$ \\
\hline $\begin{array}{l}\text { 2. Quality of prod- } \\
\text { ucts/services results }\end{array}$ & -0.01 & 1.00 & $0.34 *$ & 0.08 & $0.56^{*}$ & $0.26 *$ & $0.35 *$ & 0.17 & $0.32 *$ & 0.14 & 0.16 & -0.14 & 0.03 \\
\hline 3. Innovativeness results & 0.06 & $0.34 *$ & 1.00 & $0.24 *$ & $0.66^{*}$ & 0.07 & 0.01 & 0.09 & 0.06 & -0.06 & 0.01 & -0.12 & 0.17 \\
\hline 4. HRM results & $0.26 *$ & 0.08 & $0.24 *$ & 1.00 & $0.67 *$ & 0.11 & 0.03 & 0.20 & 0.12 & 0.12 & 0.03 & 0.16 & 0.10 \\
\hline $\begin{array}{l}\text { 5. Mean of overall perfor- } \\
\text { mance results }\end{array}$ & $0.51 *$ & $0.56^{*}$ & $0.66^{*}$ & $0.67 *$ & 1.00 & 0.11 & 0.14 & 0.15 & 0.17 & 0.09 & 0.14 & 0.10 & $0.24 *$ \\
\hline $\begin{array}{l}\text { 6. Mean of HRM signifi- } \\
\text { cance to results }\end{array}$ & -0.15 & $0.26^{*}$ & 0.07 & 0.11 & 0.11 & 1.00 & $0.39 *$ & $0.36 *$ & $0.45^{*}$ & 0.16 & $0.24 *$ & -0.05 & 0.03 \\
\hline $\begin{array}{l}\text { 7. Competitive factor: non-- } \\
\text { managerial employees }\end{array}$ & -0.07 & 0.35* & 0.01 & 0.03 & 0.14 & $0.39 *$ & 1.00 & $0.40 *$ & $0.86^{*}$ & $0.27 *$ & 0.16 & -0.05 & -0.01 \\
\hline $\begin{array}{l}\text { 8. Competitive factor: mana- } \\
\text { gerial staff }\end{array}$ & -0.06 & 0.17 & 0.09 & 0.20 & 0.15 & $0.36^{*}$ & $0.40 *$ & 1.00 & $0.81 *$ & $0.24 *$ & -0.02 & -0.01 & -0.07 \\
\hline $\begin{array}{l}\text { 9. Mean of overall human } \\
\text { factor }\end{array}$ & -0.07 & 0.32* & 0.06 & 0.12 & 0.17 & $0.45 *$ & $0.86 *$ & 0.81* & 1.00 & $0.30 *$ & 0.10 & -0.03 & -0.04 \\
\hline $\begin{array}{l}\text { 10. Mean of HRM centraliza- } \\
\text { tion }\end{array}$ & 0.05 & 0.14 & -0.06 & 0.12 & 0.09 & 0.16 & $0.27 *$ & $0.24 *$ & $0.30 *$ & 1.00 & 0.04 & 0.02 & 0.00 \\
\hline $\begin{array}{l}\text { 11. Mean of HRM knowledge } \\
\text { flow from the HQ }\end{array}$ & 0.17 & 0.16 & 0.01 & 0.03 & 0.14 & $0.24 *$ & 0.16 & -0.02 & 0.10 & 0.04 & 1.00 & $0.37 *$ & 0.16 \\
\hline $\begin{array}{l}\text { 12. Mean of HRM knowledge } \\
\text { flow to the HQ }\end{array}$ & $0.32 *$ & -0.14 & -0.12 & 0.16 & 0.10 & -0.05 & -0.05 & -0.01 & -0.03 & 0.02 & $0.37 *$ & 1.00 & $0.40 *$ \\
\hline $\begin{array}{l}\text { 13. Advancement level of } \\
\text { HRM }\end{array}$ & $0.22 *$ & 0.03 & 0.17 & 0.10 & $0.24 *$ & 0.03 & -0.01 & -0.07 & -0.04 & 0.00 & 0.16 & $0.40 *$ & 1.00 \\
\hline
\end{tabular}

Table 4. The results of a correlation test for the main research variables: company performance, competitive factors and HRM in Western Europe (source: own research data)

\begin{tabular}{|c|c|c|c|c|c|c|c|c|c|c|c|c|c|}
\hline Variables & 1. & 2. & 3. & 4. & 5. & 6. & 7. & 8. & 9. & 10. & 11. & 12. & 13. \\
\hline 1. Financial results & 1.00 & 0.06 & 0.05 & $0.23 *$ & $0.39 *$ & 0.15 & $0.20 *$ & 0.06 & 0.15 & 0.16 & 0.10 & $0.22 *$ & $0.21 *$ \\
\hline $\begin{array}{l}\text { 2. Quality of prod- } \\
\text { ucts/services results }\end{array}$ & 0.06 & 1.00 & $0.45 *$ & 0.16 & $0.59 *$ & $0.36^{*}$ & -0.02 & -0.01 & -0.03 & -0.03 & 0.16 & -0.19 & -0.19 \\
\hline 3. Innovativeness results & 0.05 & $0.45 *$ & 1.00 & $0.48 *$ & $0.80 *$ & $0.42 *$ & 0.10 & -0.07 & 0.00 & 0.17 & $0.39 *$ & 0.06 & 0.05 \\
\hline 4. HRM results & $0.23 *$ & 0.16 & $0.48 *$ & 1.00 & $0.79 *$ & $0.46^{*}$ & $0.30 *$ & 0.03 & $0.20 *$ & $0.23 *$ & $0.26 *$ & $0.19 *$ & 0.18 \\
\hline $\begin{array}{l}\text { 5. Mean of overall perfor- } \\
\text { mance results }\end{array}$ & $0.39 *$ & $0.59 *$ & $0.80 *$ & $0.79 *$ & 1.00 & $0.55 *$ & $0.25 *$ & 0.02 & 0.15 & $0.22 *$ & $0.36 *$ & 0.12 & 0.11 \\
\hline $\begin{array}{l}\text { 6. Mean of HRM signifi- } \\
\text { cance to results }\end{array}$ & 0.15 & $0.36 *$ & $0.42 *$ & $0.46^{*}$ & $0.55 *$ & 1.00 & $0.34 *$ & 0.12 & $0.27 *$ & $0.22 *$ & $0.47 *$ & $0.20 *$ & $0.24 *$ \\
\hline $\begin{array}{l}\text { 7. Competitive factor: non- } \\
\text { managerial employees }\end{array}$ & $0.20 *$ & -0.02 & 0.10 & $0.30 *$ & $0.25 *$ & $0.34 *$ & 1.00 & $0.36 *$ & $0.80 *$ & 0.19 & 0.16 & $0.34 *$ & $0.24 *$ \\
\hline $\begin{array}{l}\text { 8. Competitive factor: } \\
\text { managerial staff }\end{array}$ & 0.06 & -0.01 & -0.07 & 0.03 & 0.02 & 0.12 & $0.36 *$ & 1.00 & $0.84 *$ & 0.11 & $0.20 *$ & $\mathbf{0 . 3 4} *$ & $0.26 *$ \\
\hline
\end{tabular}


End of Table 4

\begin{tabular}{|c|c|c|c|c|c|c|c|c|c|c|c|c|c|}
\hline Variables & 1. & 2. & 3. & 4. & 5. & 6. & 7. & 8. & 9. & 10. & 11. & 12. & 13. \\
\hline $\begin{array}{l}\text { 9. Mean of overall human } \\
\text { factor }\end{array}$ & 0.15 & -0.03 & 0.00 & $0.20 *$ & 0.15 & $0.27^{*}$ & $0.80 *$ & $0.84 *$ & 1.00 & 0.18 & $0.22 *$ & $0.42^{*}$ & 0.33* \\
\hline $\begin{array}{l}\text { 10. Mean of HRM centrali- } \\
\text { zation }\end{array}$ & 0.16 & -0.03 & 0.17 & $0.23^{*}$ & $0.22 *$ & $0.22^{*}$ & 0.19 & 0.11 & 0.18 & 1.00 & 0.13 & $0.37 *$ & 0.16 \\
\hline $\begin{array}{l}\text { 11. Mean of HRM } \\
\text { knowledge flow from } \\
\text { the HQ }\end{array}$ & 0.10 & 0.16 & $0.39 *$ & $0.26^{*}$ & $0.36^{*}$ & $0.47 *$ & 0.16 & $0.20 *$ & $0.22 *$ & 0.13 & 1.00 & $0.47 *$ & 0.18 \\
\hline $\begin{array}{l}\text { 12. Mean of HRM } \\
\text { knowledge flow to the } \\
\text { HQ }\end{array}$ & $0.22 *$ & -0.19 & 0.06 & $0.19 *$ & 0.12 & $0.20 *$ & $0.34 *$ & $0.34 *$ & $0.42 *$ & $0.37 *$ & $0.47^{*}$ & 1.00 & $0.44 *$ \\
\hline $\begin{array}{l}\text { 13. Advancement level of } \\
\text { HRM }\end{array}$ & $0.21 *$ & -0.19 & 0.05 & 0.18 & 0.11 & $0.24 *$ & $0.24 *$ & $0.26^{*}$ & $0.33 *$ & 0.16 & 0.18 & $0.44 *$ & 1.00 \\
\hline
\end{tabular}

All this means that our hypothesis $\mathbf{H}_{\mathbf{1}}$ can be partially accepted because - with the exception of the results in the quality of products/services - the other two types of results are positively correlated with the HRM results.

The appraisal of the overall human factor as a company's competitive factor is positively correlated only with two fields of the company's performance results. In Eastern Europe it is correlated with the results in the quality of products/services $(r=0.32)$ and in Western Europe with the HRM results $(r=0.20)$. Similarly, the appraisal of the non-managerial employees as a competitive factor is positively correlated only with two fields of the company's performance results: in Eastern Europe with the results in the quality of products/services $(r=0.35)$ and in Western Europe with the HRM results $(r=0.30)$. No relationships between the appraisal of the managerial staff as a competitive factor and the results in four selected fields of company's performance have been found. So, our hypothesis $\mathbf{H}_{2}$ is partially confirmed, because what can be concluded is that it is only the higher appraisal of the non-managerial employees as a company's competitive factor that raises the company's performance results in HRM and the quality of products/services.

In Eastern Europe the HRM centralization is positively correlated not only with the appraisal of the overall human factor as a company's competitive factor $(r=0.30)$ but with its two components as well, i.e. non-managerial skills \& knowledge $(r=0.27)$ and managerial staff's competencies $(r=0.24)$. No relationships have been identified between the overall human factor and the significance of HRM knowledge flows either to or from the HQ. No relationships between such flows and both managerial staff and non- managerial employees have been found either. In Western Europe all looks otherwise. There are no statistically significant correlations between the appraisal of the overall human factor, including its two managerial and non-managerial components, and the centralization of HRM but there are some positive correlations with the significance of the HRM knowledge flows. The HRM knowledge flow from the HQ to its local subsidiary is associated with the appraisal of managerial staff $(r=0.20)$ and the appraisal the overall human factor $(r=0.22)$. The HRM knowledge flow to the HQ from its local subsidiary is associated with the appraisal of the overall human factor $(r=$ 0.42 ), including its two components: managerial $(r=0.34)$ and non-managerial $(r=0.34)$. Therefore our hypothesis $\mathbf{H}_{3}$ can be confirmed only to some degree. Some relationships between the selected variables are observable in Eastern Europe, whereas others in Western Europe.

In Eastern Europe the significance of HRM to the subsidiary's performance results exhibits a positive correlation with the HRM knowledge flow from the HQ to its local subsidiary $(r=0.24)$ but no statistically significant relationships with the opposite direction of HRM knowledge flow and the centralization practices of HRM. In Western Europe the significance of HRM to the subsidiary's performance results is positively correlated with HRM centralization $(r=0.22)$, and both direction of the HRM knowledge flow: from the HQ $(r=0.47)$ and to the HQ $(r=0.20)$. Hence, our hypothesis $\mathbf{H}_{4}$ can't be fully accepted. The phenomenon under study, i.e. the higher the significance of HRM to the subsidiary's performance results, the higher the HRM centralization level and the higher the significance of HRM knowledge flows from the HQ to its local subsidiary and the 
opposite direction has been identified in full only in Western Europe.

The positive relationships between the HRM advancement level and the company's performance overall results has been identified only in Eastern Europe $(r=0.24)$. But in Western Europe some other relationships that are absent in Eastern Europe have been found. Namely, the HRM advancement level is positively correlated with the significance of HRM to the company's performance results $(r=0.24)$, and the appraisal of the overall human factor $(r=0.33)$, including its two components: managerial $(r=0.26)$ and nonmanagerial $(r=0.24)$. Like in the previous case, our hypothesis $\mathbf{H}_{5}$ can't be fully accepted. Although we can say that in the whole sample the higher the HRM advancement level, the higher the company's performance overall results, the higher the appraisal of human factor (both managerial and non-managerial) as a company's competitive factor, and the higher the significance of HRM to the subsidiary's performance results - it's not true for both European regions.

Finally, all the research findings entitle us to confirm the acceptance of the hypothesis $\mathbf{H}_{6}$. We have successfully identified are some statistically significant differences between MNCs operating in Eastern and Western Europe within the range of relationships defined in the hypotheses from $\mathbf{H}_{\mathbf{1}}$ to $\mathbf{H}_{5}$.

\section{Research summary}

The comparative analysis of the empirical research findings leads to the conclusion that in the context of the main goal of the paper it is possible to indicate some similarities and differences between MNCs and their local subsidiaries operating in Eastern and Western Europe. Here they are.

In Eastern Europe the subsidiary's performance results in finance depend on the HRM results, HRM advancement level and HRM knowledge flow to the HQ. The results in the quality of products/services depend on the HRM contribution to the overall subsidiary's results, the appraisal of both non-managerial employees and the overall human factor as a company's competitive factor. The results in innovativeness depend on the results achieved within HRM, and the HRM results are connected with the financial results. Furthermore, the higher the appraisal of both nonmanagerial employees and managerial staff as a competitive factor the higher the significance of HRM to the subsidiary's performance results and the higher the centralization level of HRM. At the same time, the higher the significance of HRM to the subsidiary's performance results the more important HRM knowledge flow from the HQ to its local subsidiary.

In Western Europe the subsidiary's performance results in finance depend on the HRM results, HRM advancement level, appraisal of nonmanagerial employees as a company's competitive factor, and HRM knowledge flow to the HQ. The results in the quality of products/services depend on the HRM contribution to the overall subsidiary's results. The results in innovativeness depend on the HRM results, the HRM contribution to the overall subsidiary's results, and HRM knowledge flow from the HQ. The results in HRM are connected with the financial results, and depend on the HRM contribution to the overall subsidiary's results, the appraisal of both non-managerial employees and the overall human factor as a company's competitive factor, HRM centralization and knowledge flows in both directions: to and from the HQ. Moreover, the higher the appraisal of nonmanagerial employees as a competitive factor the higher the significance of HRM to the subsidiary's performance results. Simultaneously, the higher the significance of HRM to the subsidiary's performance results the higher HRM centralization level, and the more important the knowledge flows in both directions between the HQ and its local subsidiary. The significance of the two-direction knowledge flow is also connected with the appraisal of both non-managerial employees and managerial staff as a competitive factor.

\section{Final conclusions}

Our final conclusions based on the comparative analysis of the empirical research findings suggests that the role of human factor and HRM practices in MNCs' performance in Eastern and Western Europe takes some different shape. In Eastern Europe the human factor (both knowledge \& skills of nonmanagerial employees and competencies of managerial staff) is treated as a company's competitive factor to a higher degree than in Western Europe. What is more, in Eastern Europe the managerial staff gains higher grades than non-managerial employees, whereas in Western Europe it is on the contrary. In Eastern Europe the higher the appraisal of non-managerial employees and managerial staff as a competitive factor the higher the significance of HRM to the local subsidiary's performance results and the higher the level of HRM centralization itself. In Western Europe the higher the appraisal of non-managerial employees and 
managerial staff as a competitive factor the higher the HRM advancement level, and the significance of HRM to the local subsidiary's performance results depend exclusively on the appraisal of the skills \& knowledge of non-managerial employees. Additionally, the higher level of HRM centralization brings better results in HRM itself as well as in the overall performance results. It's also worth noticing that in Eastern Europe the higher the HRM advancement level the better the company's financial and overall performance results, whereas in Western Europe the HRM advancement level is associated not only with financial results but also with the contribution of HRM to the overall performance results, the appraisal of human factor (both managerial and non-managerial) and twodirection HRM knowledge flow between the HQ ant its subsidiary.

We hope the reader can find the main goal of the article realized. In accordance with our intention, we have answered all our research questions and verified the corresponding hypotheses. All this help us to identify some regularities within the problems under study in two European regions and then formulate the appropriate conclusions.

However, the study is not free of some limitations. Albeit the research sample was deliberatively selected, it covered only those MNCs that were headquartered in one Central European country. Therefore, the final conclusions can't be extended on the whole population of MNCs worldwide. Furthermore, although the sample was diverse in terms of the type of business activity according to the ECBA, not all sectors of economy were represented. Additionally, a very small percentage of foreign subsidiaries was established as a brownfield investment, so this might have some effect on the collected research data as well. Some other flaws are also discernible in the measurement scales or the calculations based exclusively on the mean values. As about the latter ones they may averagize or generalize the studied variables too much. There are also some reservations about asking the informants the general questions about the company's performance results instead of using hard performance indicators. Of course this practice is not at odd within this type of research, however it may undermine the subjectivity of evaluation. And as about the future research we would recommend to look for some mediating variables that may explain in details or discover new ties between the variables under study.

Notwithstanding all these imperfection, the value of this paper is visible. We have successfully identified some statistically significant differences between MNCs operating in Eastern and Western Europe within the range of relationships between the activities in the field of HRM and performance results with a view to the value ascribed to human resources as a strategic competitive factor, HRM centralization practices and the importance of HRM knowledge flows between the HQs and their subsidiaries. Our study, therefore, represents an original effort at examining these relationships and brings some considerable contribution to the development of management scientific discipline, in particular to human resources management. And to our best knowledge, among the predominant number of articles devoted to MNCs headquartered in the Western and more developed countries, it is probably the first one to take the Eastern European perspective from the former centrally-planned economies on MNCs originating from this region.

As for the practical implications of the research results, they mostly rely on indicating some similarities and differences between MNCs and their foreign entities in two European regions that may have an impact on managerial interpretations on which HRM practices should be considered as effective and which as possibly ineffective with connection to the organizational performance. It's worth emphasizing that the effectiveness itself is not only determined by the local managers' and employees' competencies and perceived work results. It also depends on how human factor is appraised as a competitive factor and what HRM advancement and centralization levels are offered as recognition in response. Hence, the presented research findings may help the managers of MNCs to uncover some hidden opportunities existing in the management practice of their regional business and inspire them to create such managerial developments which can successfully cope with HRM regional and foreign country level challenges.

\section{Funding}

This work was supported by National Science Center, Poland [No 2016/23/B/HS4/00686].

\section{References}

Activities of enterprises having foreign entities in 2015. (2017). Central Statistical Office, Warsaw.

Al-Hakim, L. A., \& Hassan, S. (2016). Core requirements of knowledge management implementation, innovation and organizational performance. Journal of Business Economics and Management, 17(1), 109-124.

https://doi.org/10.3846/16111699.2012.720597 
Andersen, O. (1993). On the internationalization process of firms: A critical analysis. Journal of International Business Studies, 24(2), 209-231. https://doi.org/10.1057/palgrave.jibs.8490230

Apsalone, M., \& Šumilo, Ē. (2015). Socio-cultural factors and international competitiveness. Business, Management and Education, 13(2), 276-291. https://doi.org/10.3846/bme.2015.302

Arthur, J. B. (1994). Effects of human resource systems on manufacturing performance and turnover. Academy of Management Journal, 37(3). https://doi.org/10.5465/256705

Avarmaa, M., Hazak, A., \& Männasoo, K. (2013). Does leverage affect labour productivity? A comparative study of local and multinational companies of the Baltic countries. Journal of Business Economics and Management, 14(2), 252-275. https://doi.org/10.3846/16111699.2011.651624

Barney, J. (1991). Firm resources and sustained competitive advantage. Journal of Management, 17(1), 99-120. https://doi.org/10.1177/014920639101700108

Beatty, R. W., Huselid, M. A., \& Schneier, C. E. (2003). The new HR metrics: Scoring on the business scorecard. Organizational Dynamics, 32(2), 107121. https://doi.org/10.1016/S0090-2616(03)00013-5

Becker, B. E., Huselid, M. A., \& Ulrich, D. (2001). The HR scorecard: Linking people, strategy, and performance. Harvard Business School Press, Boston.

Becker, B., \& Gerhart, B. (1996). The impact of human resource management on organizational performance: Progress and prospects. Academy of Management Journal, 39(4), 779-801. https://doi.org/10.2307/256712

Beer, M., Spector, B., Lawrence, P. R., Mills, D. Q., \& Walton, R. E. (1984). Managing human assets. The Free Press, New York.

Berchtold, S., Pircher, R., \& Stadler, C. (2010). Global integration versus local adaptation: A case study of Austrian MNCs in Eastern Europe. European Journal of International Management, 4(5), 524549. https://doi.org/10.1504/EJIM.2010.034965

Birdi, K., Clegg, C., Patterson, M., Robinson, A., Stride, C., Wall, T., \& Wood, S. (2008). The impact of human resource and operational management practices on company productivity: A longitudinal study. Personnel Psychology, 61(3), 467-501. https://doi.org/10.1111/j.1744-6570.2008.00136.x

Birkinshaw, J., Hood, N., \& Honsson, S. (1998). Building firm - specific advantages in multinational corporations: The role of subsidiary initiative. Strategic Management Journal, 19(3), 221-242. https://doi.org/10.1002/(SICI)1097-0266(199803) 19:3<221::AID-SMJ948>3.0.CO;2-P

Bjorkman, I., Barner-Rasmussen, W., \& Li, L. (2004). Managing knowledge transfer in MNCs: the impact of headquarters control mechanisms, Journal of International Business Studies, 35, 443-455. https://doi.org/10.1057/palgrave.jibs.8400094

Brauer, M. F. (2013). The effects of short-term and long-term oriented managerial behavior on medium-term financial performance: Longitudinal evidence from Europe. Journal of Business Economics and Management, 14(2), 386-402. https://doi.org/10.3846/16111699.2012.703965

Brewster, C. (2007). European perspective on HRM. European Journal of International Management, 1(3). https://doi.org/10.1504/EJIM.2007.014696

Brewster, C., Morley, M., \& Bučiūnienė, I. (2010). The reality of human resource management in Central and Eastern Europe: A special issue to mark the $20^{\text {th }}$ anniversary of Cranet (the Cranfield Network on Comparative Human Resource Management). Baltic Journal of Management, 5(2), 145-155. https://doi.org/10.1108/17465261011045098

Brunet-Thornton, R. (2017). Foreword to the special edition, the return to Europe: A generation of reinventing national identities. Baltic Journal of Management, 12(1), 2-5. https://doi.org/10.1108/BJM-10-2016-0239

Chanda, A., \& Shen, J. (2009). HRM strategic integration and organizational performance. Sage publication Inc, Los Angeles.

Chen, H. L. (2014). Innovation stimulants, innovation capacity, and the performance of capital projects. Journal of Business Economics and Management, 15(2), 212-231. https://doi.org/10.3846/16111699.2012.711361

Chen, M. J. (2016). Competitive dynamics: Eastern roots, Western growth. Cross Cultural \& Strategic Management, 23(4), 510-530. https://doi.org/10.1108/CCSM-05-2016-0098

Combs, C., Liu, Y., Hall, A., \& Ketchen, D. (2006). How much do high-performance work systems matter? A meta-analysis of their effects on organizational performance. Personnel Psychology, 59(3), 501-528. https://doi.org/10.1111/j.1744-6570.2006.00045.x

Delery, J. E., \& Roumpi, D. (2017). Strategic human resource management, human capital and competitive advantage: is the field going in circles? $\mathrm{Hu}$ man Resource Management Journal, 27(1), 1-21. https://doi.org/10.1111/1748-8583.12137

Dickmann, M., Brewster, C., \& Sparrow, P. (Ed.). (2016). International human resource management. Contemporary HR Issues in Europe. Taylor $\&$ Francis, New York. https://doi.org/10.4324/9781315773483

Doornich, J. B. (2018). Managerial learning form social capital during internationalization. International Business Review, 27(4), 877-892. https://doi.org/10.1016/j.ibusrev.2018.01.010

Dyer, L. (1993). Human resources as a source of competitive advantage. Cornell University ILR School, Ithaca, New York. 
Farndale, E., Raghuram, S., Gully, S., Liu, H., Phillips, J., \& Vidović, M. (2017). A Vision of International Human Resource Management Research. International Journal of Human Resource Management, 28(12), 1625-1639. https://doi.org/10.1080/09585192.2017.1308416

Ferencikova, S., \& Hluskova, T. (2015). Internationalization of Central and Eastern European companies - theory and its implications in the Slovak IT sector. Journal of East European Management Studies, 20(4), 415-434. https://doi.org/10.5771/0949-6181-2015-4-415

Ferguson, K. L., \& Reio, T. G. (2010). Human resource management systems and firm performance. Journal of Management Development, 29(5), 471-494. https://doi.org/10.1108/02621711011039231

Festing, M., \& Sahakiants, I. (2013). Path-dependent evolution of compensation systems in Central and Eastern Europe: A case study of multinational corporation subsidiaries in the Czech Republic, Poland and Hungary. Europen Management Journal, 31(4), 373-389. https://doi.org/10.1016/j.emj.2013.01.005

Ghoshal, S., \& Nohria, N. (1993). Horses for courses: Organizational forms for multinational corporations, Sloan Management Review, Winter.

Ginevičius, R., Krivka, A., \& Šimkūnaitè, J. (2010). The model of forming competitive strategy of an enterprise under the conditions of oligopolic market. Journal of Business Economics and Management, 11(3), 367-395. https://doi.org/10.3846/jbem.2010.18

Gomezelj, D. O., \& Antončič, B. (2015). Employees' knowledge determinants in SMEs: The case of Slovenia. Journal of Business Economics and Management, 16(2), 422-444. https://doi.org/10.3846/16111699.2012.734326

Götz, M. (2014). Polskie bezpośrednie inwestycje za granica. Metodologia teorii ugruntowanej. Instytut Zachodni, Poznań.

Guest, D. (1997). Human resource management and performance: A review and research agenda. International Journal of Human Resource Management, 8(3), 263-276. https://doi.org/10.1080/095851997341630

Guest, D., Paauwe, J., \& Wright, P. (2011). Human resource management and performance: What's next? Chichester: Wiley.

Haromszeki, Ł. (2014). Expected features and the behavior of talented leaders in the three sectors of the Polish economy in context with other CentralEastern European Countries. Journal of Intercultural Management, 6(4), 81-100. https://doi.org/10.2478/joim-2014-0037

Huselid, M. A., \& Becker, B. E. (2011). Bridging micro and macro domains: Workforce differentiation and strategic human resources management. Journal of
Management, 37(2), 421-428.

https://doi.org/10.1177/0149206310373400

Huselid, M. A. (1995). The impact of human resource management practices on turnover productivity and corporate financial performance. Academy of Management Journal, 38(3), 635-672. https://ssrn.com/abstract=1803666

Huselid, M. A., Jackson, S. E., \& Schuler, R. S. (1997). Technical and strategic human resource management effectiveness as determinants of firm performance. Academy of Management Journal, 40(1), $171-188$.

Hyder, A. S., \& Abraha, D. (2008). Institutional factors and strategic alliances in Eastern and Central Europe. Baltic Journal of Management, 3(3), 289 308 . https://doi.org/10.1108/17465260810902379

Ingham, J. (2007). Strategic human capital management: Creating value through people. Elsevier/ Butterworth-Heinemann, Amsterdam.

https://doi.org/10.1016/B978-0-7506-8134-6.50010-0

Juchnowicz, M. (2014). Satysfakcja zawodowa pracowników - kreator kapitalu ludzkiego. PWN, Warszawa.

Karaszewski, W. (2013). Aktywność inwestycyjna polskich przedsiębiorstw za granica. PWE, Warszawa.

Karoliny, Z., Farkas, F., \& Poor, J. (2009). In focus: Hungarian and Central Eastern European Characteristics of human resource management - An international comparative survey. Journal for East European Management Studies, 14(1), 9-47. https://doi.org/10.5771/0949-6181-2009-1-9

Katou, A. A., \& Budhwar, P. S. (2010a). Causal relationship between HRM policies and organisational performance: Evidence from the Greek manufacturing sector. European Management Journal, 28(1), 25-39.

https://doi.org/10.1016/j.emj.2009.06.001

Katou, A. A., \& Budhwar, P. S. (2010b). Testing competing HRM-performance linkage models: evidence from the Greek manufacturing sector. European Journal of International Management, 4(5), 464-487. https://doi.org/10.1504/EJIM.2010.034962

Kazlauskaitè, R., \& Bučiūnienè, I. (2010). Disclosing HRM-performance linkage: Current research status and future directions. Transformations in Business and Economics, 9(2), 303-317.

Kearns, P. (2010). HR strategy: Creating business strategy with human capital. Elsevier, Amsterdam. https://doi.org/10.4324/9781856179379

Kiselakova, D., Sofrankova, B., Onuferova, E., \& Cabinova, V. (2019). The evaluation of competitive position of EU-28 economies with using global multi-criteria indices. Equilibrium. Quarterly Journal of Economics and Economic Policy, Institute of Economic Research, 14(3), 441-462. https://doi.org/10.24136/eq.2019.021 
Kogut, B., \& Zander, U. (1993). Knowledge of the firm and the evolutionary theory of the multinational corporation. Journal of International Business Studies, 24(4), 625-645.

https://doi.org/10.1057/palgrave.jibs.8490248

Koster, F., \& Wittek, R. (2016). Competition and constraint: Economic globalization and human resource practices in 23 European countries. Employee Relations, 38(2), 286-303. https://doi.org/10.1108/ER-11-2014-0130

Kshetri, N. (2010). Business perceptions of regulative institutions in Central and Eastern Europe. Baltic Journal of Management, 5(3), 356-377. https://doi.org/10.1108/17465261011079758

Kupczyk, T., \& Stor, M. (2017). Competency management. Theory, research and business practice. Wyższa Szkoła Handlowa, Wrocław.

Latusek-Jurczak, D. (2014). Polskie przedsiębiorstwa w Dolinie Krzemowej. Wydawnictwo Poltex, Warszawa.

Listwan, T., Pocztowski, A., \& Stor, M. (2009). Human resources management in Poland. In Human Resources Management in Eastern and Central Europe. M. J. Morley, N. Heraty, \& S. Michailova (Eds.). Routledge. London, New York.

MacDuffie, J. P. (1995). Human resource bundles and manufacturing performance: Organizational logic and flexible production systems in the world auto industry. Industrial and Labor Relations Review, 48(2), 197-221. https://doi.org/10.1177/001979399504800201

Mayo, A. (2012). Human resources or human capital? Managing people as assets. Routlege, New York.

Morley, M. J., Heraty, N., \& Michailova, S. (Eds.). (2009). Human resources management in Eastern and Central Europe. Routledge. London, New York.

Nagy, M. S. (2002). Using a single-item approach to measure facet job satisfaction. Journal of Occupational and Organizational Psychology, 75(1), 7786. https://doi.org/10.1348/096317902167658

Nasab, S., Farhangnejad, A., \& Naysary, B. (2013). Casting a resource-based view on intangible assets and export behavior. Business, Management and Education, 11(2), 315-332. https://doi.org/10.3846/bme.2013.18

Paawe, J., \& Ferndale, E. (2017). Strategy, HRM, and performance. A contextual approach. Oxford University Press.

Pfeffer, J., \& Veiga, J. F. (1999). Putting people first for organizational success. The Academy of Management Executive, 13(2), 37-48. https://doi.org/10.5465/ame.1999.1899547

Poór, J., Engle, A., \& Brewster, C. (Eds.). (2017). HRM in transition-practices of $M N C$-subsidiaries in Central and Eastern Europe, Russia and Kazakhstan (2015-2016). Selye University, Komárno.
Rajnoha, R., Merková, M., Dobrovič, J., \& Rózsa, Z. (2018). Business performance management and FDI: Key differences between foreign and domestic-owned firms - a case of Slovakia. Journal of Business Economics and Management, 19(1), 4262. https://doi.org/10.3846/jbem.2018.1538

Rich, B., Lepine, J., \& Crawford, E. (2010). Job engagement: Antecedents and effects on job performance. Academy of Management Journal, 53(3). https://doi.org/10.5465/amj.2010.51468988

Richey, B., \& Wally, S. (1998). Strategic human resource strategies for transnationals in Europe. $\mathrm{Hu}$ man Resource Management Review, 8(1), 79-97. https://doi.org/10.1016/S1053-4822(99)80040-0

Sahadev, S., \& Demirbag, M. (2010). A comparative analysis of employment practices among post-communist and capitalist countries in South Eastern Europe. Employee Relations, 32(3), 248261. https://doi.org/10.1108/01425451011038780

Schuler, R., \& Jackson, S. (1987). Linking competitive strategies with human resource management practices. Academy of Management Executive, 1(3), 207-219. https://doi.org/10.5465/ame.1987.4275740

Sienkiewicz, Ł. (2014). Competency-based human resources management. The lifelong learning perspective. Instytut Badań Edukacyjnych, Warsaw.

Skare, M., \& Porada-Rochoń, M. (2019). Financial and economic development link in transitional economies: A spectral Granger causality analysis 1991(2017. Oeconomia Copernicana, 10(1), 7-35. https://doi.org/10.24136/oc.2019.001

Slangen, A. H. (2011). A communication-based theory of the choice between greenfield and acquisition entry. Journal of Management Studies, 48(8), 1699-1726. https://doi.org/10.1111/j.1467-6486.2011.01013.x

Sparrow, P., Shipton, H., Budhwar, P., \& Brown, A. (Eds.). (2016). Human resources management, innovation and performance. Palgrave Macmillan, London. https://doi.org/10.1057/9781137465191

Stawicka, M. K. (2014). Determinants of foreign direct investment inflows in Central and Eastern European countries. Oeconomia Copernicana, 5(2), 7-20. https://doi.org/10.12775/OeC.2014.010

Stor, M., \& Suchodolski, A. (2016). Istotność wybranych subfunkcji ZZL Z perspektywy wyników uzyskiwanych przez przedsiębiorstwa polskie i zagraniczne w Polsce. Zarzadzanie $i \mathrm{Fi}$ nanse, 14(2/2).

Stor, M. (2014). Reconceptualizing strategic international human resources management in pursuing sustainable competitive advantage of MNCs. $\mathrm{Hu}$ man Resource Management, 6(10).

Stor, M. (2016). Paradoxical and nonparadoxical oxymora in strategies of competency management research reflections. Research Paper of Wroctaw University of Economics, 2(27). 
Stor, M., \& Haromszeki, Ł. (2019). Organizational leadership practices in MNCs: The effect of the HRs value as a competitive factor and the FDI structure. Journal of Transnational Management, 24(2), 83-121. https://doi.org/10.1080/15475778.2019.1608748

Stor, M., \& Kupczyk, T. (2015). Differences in competency management - comparative analysis between Polish, Spanish, and Austrian business practices. Journal of Intercultural Management, 7(2), 49-74. https://doi.org/10.1515/joim-2015-0010

Trąpczyński, P. (2015). Foreign direct investment strategies and performance in the internationalization of Polish companies. Difin, Warszawa.

Villajos, E., Tordera, N., Peiró, J. M., \& van Veldhoven, M. (2019). Refinement and validation of a comprehensive scale for measuring HR practices aimed at performance-enhancement and employeesupport. European Management Journal, 37(3), 387-397. https://doi.org/10.1016/j.emj.2018.10.003

Wang, P., Tong, T. W., \& Koh, C. P. (2004). An integrated model of knowledge transfer from MNC parent to China subsidiary. Journal of World Business, 39(2), 168-182. https://doi.org/10.1016/j.jwb.2003.08.009

Wilkinson, A., \& Wood, G. (2017). Global trends and crises, comparative capitalism and HRM. The
International Journal of Human Resource Management, 28(18), 2503-2518. https://doi.org/10.1080/09585192.2017.1331624

Witek-Hajduk, M. K. (2010). Strategie internacjonalizacji polskich przedsiębiorstw $w$ warunkach akcesji Polski do Unii Europejskie. Szkoła Główna Handlowa, Warszawa.

Wright, P. M., McMahan, G. C., \& McWilliams, A. (1993). Human resources as sustained competitive advantage: a resource-based perspective. Center for Effective Organizations. Marshall School of Business. University of Southern California, Los Angeles.

Wright, P. M., \& Snell, S. A. (1991). Toward an integrative view of strategic human resource management. Human Resource Management Review, 1(3), 203-225. https://doi.org/10.1016/1053-4822(91)90015-5

Żarnik-Żuławska, J. (2016). Strategiczne zarzadzanie kapitałem ludzkim $w$ oparciu o zrównoważona karte wyników. Wydawnictwo Naukowe Uniwersytetu Mikołaja Kopernika, Toruń.

Zoghi, C., \& Mohr, R. D. (2011). The decentralization of decision making and employee involvement within the workplace: Evidence from four establishment datasets. British Journal of Industrial Relations, 49(4), 688-716. https://doi.org/10.1111/j.1467-8543.2010.00838.x 